\title{
Estrogenic Potential of Flemingia vestita Benth Tubers in Ovariectomized Rat Model
}

\author{
Sunita Shailajan ${ }^{1 *}$, Suman Kumaria², Suhas Pednekar', Sasikumar Menon ${ }^{3}$, Hiranjit Choudhury ${ }^{2}$ and Archana Matani ${ }^{1}$ \\ 'Herbal Research Lab, Ramnarain Ruia College, Matunga (East), Mumbai-400019, India. \\ ²Department of Botany, North-Eastern Hill University, Umshing Mawkynroh, Shillong-793022, Meghalaya, India. \\ Institute for Advanced Training and Research in Interdisciplinary Sciences, 194, Scheme No. 6, Road No. 15, Sion Koliwada, Sion (E), Mumbai-400022, India.
}

\begin{abstract}
Objective: This study investigates the potential estrogenic activity of the ethanolic extract of Flemingia vestita Benth tubers using ovariectomized rat model. Materials and Methods: The ethanolic extract of $F$. vestita tubers has been standardized using validated HPLC method in terms of its genistein content $(8.43 \pm 0.05 \mathrm{mg} / \mathrm{g}$ of extract). Three to four week old young albino Wistar female rats were ovariectomized and treated for 14 days post ovariectomy with the standardized ethanolic extract at three different dose levels $(100,250,500 \mathrm{mg} / \mathrm{kg}$ body weight) with a positive control of Estradiol valerate $(1 \mathrm{mg} / \mathrm{kg} /$ day). The parameters evaluated were uterine weight, uterine glycogen, G6PDH, LDH, 17ß-estradiol, progesterone, total cholesterol, triglycerides, HDL and histo architecture of uterus. Results: Treatment with the ethanolic extract of $F$. vestita tubers showed dose dependent increase in uterine weight, glycogen levels, G6PDH levels, estrogen and progesterone levels when compared with the ovariectomized control. Amongst three dose levels, high dose of plant extract showed significant increase in the uterine weight $(p<0.001)$, uterine glycogen content $(p<0.001), 17-\beta$ estradiol and progesterone levels ( $p<0.001)$, G6PDH and LDH levels $(p<$
\end{abstract}

0.001 ) as well as significant decrease in HDL and triglycerides levels ( $p<$ 0.001 ) compared to ovariectomized control. Histopathological evaluation of uteri sections revealed that the high dose of the plant show increase in the endometrial response as indicated by proliferation of endometrial glands and luminal epithelium of the ovariectomized rats. Conclusion: Thus, these data suggests that ethanolic extract $(500 \mathrm{mg} / \mathrm{kg}$ body weight) of $F$. vestita tubers may exhibit good estrogenic activity in ovariectomized rat model.

Key words: Estrogenic activity, Flemingia vestita, Genistein, HPLC, Ovariectomized rats.

Address for Correspondence:

Dr. Sunita Shailajan, Associate Professor in Botany Herbal Research Lab, Ramnarain Ruia College, Matunga (East), Mumbai-400019, India.

Tel no: 022 24154390, Fax no: 022 24142480,

E-mail: sunitashailajan@gmail.com

DOI : 10.5530/pj.2016.1.10

\section{INTRODUCTION}

Phytoestrogens, specifically isoflavones, are receiving great commercial interest at present. As these phytoesterogens have structural similarity to estrogenic steroids in human body, they mimic the effects of naturally occurring estrogenic compounds. Specifically the biological effects associated with ingesting isoflavones indicate that dietary supplements rich in these compounds might be useful for alleviating menopausal health concerns. ${ }^{1-2}$ Several medicinal plants have been evaluated for their estrogenic activity either individually or in the form of polyherbal combination..$^{3-8}$

There have been very few studies on the pharmacological validation of the plants that are used for the treatment of diseases in North-East India. One such plant is Flemingia vestita Benth (Soh-phlang, Fabaceae); an indigenous plant of Meghalaya, found practically throughout the Himalayas and Khasi Hills up to an elevation of 8,000 ft. ${ }^{9}$ The plant is known for its fleshy tubers which are scientifically evaluated against intestinal helminthes infections. ${ }^{10-11}$ These tubers are consumed by local people of Meghalaya to cure intestinal infections. ${ }^{12}$ These tubers possess major isoflavones like formononetin, diadzein, genistein, etc. ${ }^{13-15}$ Genistein is known to have a wide spectrum of biological activities, ${ }^{16}$ estrogenic activity being one of its most remarkable properties. ${ }^{17-18}$ Moreover, no research so far has been conducted to assess estrogenic potential of $F$. vestita. Hence, the present study aimed to evaluate the estrogenic activity of standardized extract of $F$. vestita tubers in ovariectomized rat model.

\section{MATERIALS AND METHODS}

\section{Plant materials}

Fresh tubers of F. vestita were collected from Shillong (Meghalaya) and authenticated from Department of Botany, North East Hill University, Shillong. The tubers were thoroughly washed, cleaned and shade dried for a week. The materials were then packed in absorbent paper; oven dried at $37^{\circ} \mathrm{C}$ for three days, powdered using a mixer-grinder and sieved (BSS mesh number 85).

\section{Chemicals and reagents}

Analytical grade solvents were purchased from Merck Specialities, Mumbai, India. Progynova (Estradiol valerate tablets) was procured from Zydus Healthcare. Ketamine Hydrochloride injection was procured from Neon Laboratories Ltd. The estrogen and progesterone kits were obtained from Diametra, Italy and G6PDH kit was obtained from Avecon healthcare. The LDH reagent kit was obtained from Aspen Laboratories and cholesterol, HDL and triglycerides kits were obtained from Span diagnostics. Standard genistein (98\% purity) was procured from Sigma Aldrich Chemical Company (Steinheim, Germany). Healex plus spray was procured from Shreya Life Sciences Pvt. Ltd. Surgical staplers were obtained from Eticon Endo Surgery (Mexico).

\section{Preparation of ethanolic extract and standardization}

Fine powder of $F$. vestita tubers ( $300 \mathrm{~g})$ was extracted with ethanol (1500 $\mathrm{mL}, 5 \mathrm{X})$ by refluxing on heating mantle $(30 \%)$ for $5 \mathrm{~h}$. The mixture was filtered through Whatmann filter No. 1 and the filtrate was evaporated under reduced pressure using a rota evaporator at $45^{\circ} \mathrm{C}$. The extract was standardized in terms of genistein content using validated HPLC method. ${ }^{19}$ Separation was achieved on Cosmosil $\mathrm{C}_{18}$-column (150 mm x 4.6 $\mathrm{mm}, 5.0 \mu \mathrm{m}$ ) using mobile phase $0.025 \mathrm{M}$ phosphate buffer (in water): acetonitrile (68: 32, v/v, $\mathrm{pH} 2.4$ ) delivered at a flow rate of $1 \mathrm{~mL} / \mathrm{min}$. The peaks were recorded at $261 \mathrm{~nm}$ using PDA detector (MD- 1510). The presence of genistein in the extract was also confirmed using LCMS technique. Mass spectrometric analysis was performed on an API 
Applied Biosystems Hybrid Q- Trap API 2000 Mass Spectrometer (AB- MDS Sciex, Toronto, Canada) equipped with an electrospray ionization source (ESI).

\section{Animals}

Albino Wistar female rats weighing 150-180 g and 180-220 g were used for safety and estrogenic study, respectively. Animals were obtained from Haffkine Biopharmaceuticals, Parel and were housed in polypropylene cages under regulated temperature of $22 \pm 3^{\circ} \mathrm{C}$, relative humidity of 60 $\pm 5 \%$ and $12 \mathrm{~h}$ light-dark cycle. Animals were provided free access to standard water and food supplied by Amrut Feed. The experimental procedures and protocol for the safety (AMM-130626-01) and efficacy (AMM-130626-02) study were reviewed and approved by the Institutional Animal Ethics Committee (IAEC) of Ramnarain Ruia College, Mumbai (CPCSEA/315).

\section{Safety evaluation}

The safety of the standardized ethanolic extract of $F$. vestita was evaluated in female albino Wistar rats at a dose of $2000 \mathrm{mg} / \mathrm{kg}$ as per OECD guidelines No. $420 .{ }^{20}$ The animals were randomly grouped into three groups of five animals each. Group I served as normal control received Distilled water, Group II served as vehicle control received $1 \%$ CMC and Group III received ethanolic extract of F. vestita tubers. After dosing, the animals were observed after every 30 min till $2 \mathrm{~h}$ for immediate toxicity, periodically during the first $48 \mathrm{~h}$ and then daily for 14 days. Toxicity was evaluated on the basis of mortality, daily food and water intake, change in body weight and general behavioral changes.

\section{Experimental design for evaluating estrogenic potential}

Estrogenic potential of standardized extract of $F$. vestita was evaluated in ovariectomized rats at three different doses $(100 \mathrm{mg} / \mathrm{kg}, 250 \mathrm{mg} /$ $\mathrm{kg}$ and $500 \mathrm{mg} / \mathrm{kg}$, body weight respectively). Histopathological parameters, uterine weight, glycogen content and biochemical parameters like $17-\beta$ estradiol, progesterone, lactate dehydrogenase (LDH), glucose-6-phosphatase (G6PDH), total cholesterol, triglycerides and High-density lipoprotein (HDL) were used to evaluate the estrogenic potential.

Vaginal smear cytology was performed for the determination of rat estrous cycle phases and to ensure the regular cycles. Vaginal secretions were examined from all the animals every morning for 15 days. ${ }^{21-22}$ Rats showing diestrous phase (leukocyte cells) were selected for the procedure of ovariectomy.

Albino Wistar female rats were randomized into six groups of six animals each. Animals from all the groups were ovariectomized (OVX) except the rats from the Group I that served as sham-operated control. In the sham-operated control, the ovaries were exposed and gently manipulated but not excised. On rest of the animals bilateral ovariectomy was performed via a dorso-lateral approach with a small lateral vertical skin incision followed by ligation and excision of the ovaries along the upper horn under general anesthesia with ketamine hydrochloride $\left(100 \mathrm{mg} / \mathrm{kg}\right.$ body weight, i.p.). ${ }^{23-24}$ The incisions were joined together with the help of surgical stapler followed by applying healex spray for quick healing of the wound. Care was taken to avoid any infection throughout the ovariectomy procedure. Animals were kept for the healing period of 14 days pre dosing. During the healing period, the animals were observed for any abnormal behavior or side effects. The animals were then randomized in 5 groups (except sham-operated control) on the basis of $17-\beta$ estradiol and progesterone levels. Animals showing reduced levels of estrogen and progesterone were then orally administered with their respective test samples as per dosage regimen for 14 consecutive days. The experimental groups were as follows;

\begin{tabular}{|c|c|c|c|}
\hline $\begin{array}{c}\text { Group } \\
\text { no. }\end{array}$ & Group details & Code & Treatment \\
\hline I & $\begin{array}{l}\text { Normal control (Sham } \\
\text { operated) }\end{array}$ & $\mathrm{NC}$ & $\begin{array}{c}1 \% \mathrm{CMC} \\
\text { (Carboxymethlycellulose) }\end{array}$ \\
\hline II & Ovariectomized control & ovx & $1 \% \mathrm{CMC}$ \\
\hline III & Estradiol valerate & EV & $1 \mathrm{mg} / \mathrm{kg}$ body weight ${ }^{[25]}$ \\
\hline IV & $\begin{array}{c}\text { Low dose of Flemingia } \\
\text { vestita extract }\end{array}$ & FVL & $100 \mathrm{mg} / \mathrm{kg}$ body weight \\
\hline $\mathbf{V}$ & $\begin{array}{c}\text { Medium dose of Flemingia } \\
\text { vestita extract }\end{array}$ & FVM & $250 \mathrm{mg} / \mathrm{kg}$ body weight \\
\hline VI & $\begin{array}{l}\text { High dose of Flemingia } \\
\text { vestita extract }\end{array}$ & $\mathrm{FVH}$ & $500 \mathrm{mg} / \mathrm{kg}$ body weight \\
\hline
\end{tabular}

Cage side observations including general behavioral changes, daily food and water consumption and daily weight changes were observed during the healing period of 14 days and after dosing for 14 days.

\section{Blood collection procedure}

Blood sample was withdrawn from all the animals prior to dosing (Day 0 ) and on day 15 (post dosing) by retro orbital plexus technique using heparinised capillaries. The whole blood, serum and plasma samples collected during the study were stored at $-20^{\circ} \mathrm{C}$ until the determination of biochemical parameters.

\section{Histopathological evaluation}

The animals were sacrificed by cervical dislocation after blood collection. The left and right uterus of all the animals were removed after sacrifice, rinsed in saline, blotted and weighed. The weight of the uterus was expressed as $\mathrm{mg} / 100 \mathrm{~g}$ body weight. ${ }^{2}$ A portion of uterus was taken for the estimation of glycogen by anthrone method ${ }^{26}$ and remaining was fixed in $10 \%$ neutral buffered formalin and processed by paraffin technique. Sections of $5 \mu \mathrm{m}$ thickness were cut and stained by routine hematoxylineosin (H\&E) method for histopathological evaluation. ${ }^{27}$

\section{Evaluation of Biochemical parameters}

Serum samples were used to determine the $17-\beta$ estradiol and progesterone levels along with the estimation of $\mathrm{LDH}$ levels. The whole blood sample was used to estimate G6PDH levels whereas plasma samples were used to determine total cholesterol, HDL and triglycerides levels. The standard kits were used to evaluate biochemical parameters like 17- $\beta$ estradiol, progesterone, G6PDH, LDH, total cholesterol, HDL and triglycerides levels.

\section{Statistical analysis}

Values are expressed as Mean \pm SEM, $n=6$. Graph Pad Prism5 software (version 5.03) was used for the statistical analysis of data. Data was analyzed using ANOVA followed by Dunnett's test. Values of $\mathrm{p}<0.05$ were considered significant.

\section{RESULTS AND DISCUSSION}

Tubers of Flemingia vestita Benth has been reported to possess phytoestrogens such as formononetin, pseudobaptigenin, diadzein and genistein. ${ }^{15}$ Recently, much interest has been paid to phytoestrogens for their potential health benefits in counteracting menopausal symptoms and in lowering the incidence of hormone dependent diseases. ${ }^{28}$ Genistein is one such phytoestrogen with a wide variety of pharmacological effects in animal cells, including tyrosine kinase inhibition, and dietary genistein ingestion has been linked, through epidemiological and animal model studies, with a 
range of potential health beneficial effects. These include chemoprevention of breast and prostate cancers, cardiovascular disease and post-menopausal ailments. ${ }^{29}$ Hence, genistein was selected as a bioactive marker for evaluating the estrogenic potential of $F$. vestita tubers using ovariectomized rat model.

\section{Standardized ethanolic extract of $F$. vestita}

The ethanolic extract of the plant was standardized in terms of its genistein content $(8.43 \pm 0.05 \mathrm{mg} / \mathrm{g})$ using a validated HPLC method reported previously. ${ }^{19}$ The HPLC chromatograms of genistein and ethanolic extract of $F$. vestita are shown in Figure 1.The presence of genistein in the ethanolic extract of $F$. vestita tubers was also confirmed by using LC-MS technique.

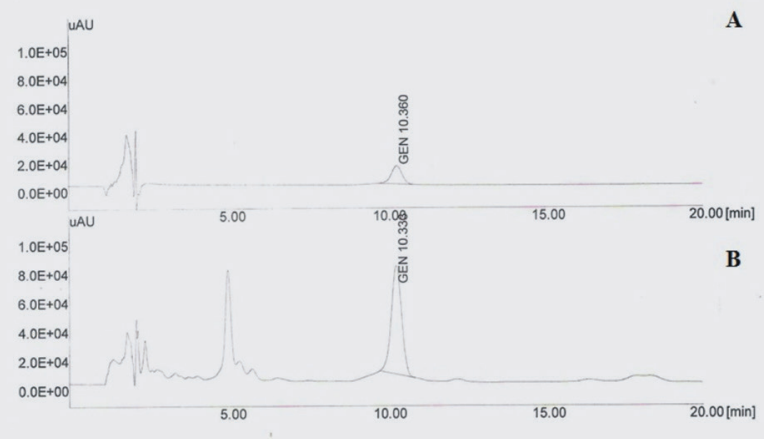

Figure 1: HPLC chromatogram of A) standard genistein $(2 \mu \mathrm{g} / \mathrm{mL})$ and B) ethanolic extract of $F$. vestita tubers

The molecular mass of genistein is 270.241. As the mass spectrometric analysis was carried out at negative ionization mode, the mass of genistein obtained was found to be $269.8 \mathrm{~m} / \mathrm{z}$. The peak corresponding to genistein was observed at m/z 269.8 in the Full scan Q1 MS spectrum of the ethanolic extract of $F$. vestita tubers confirming its presence (Figure 2).
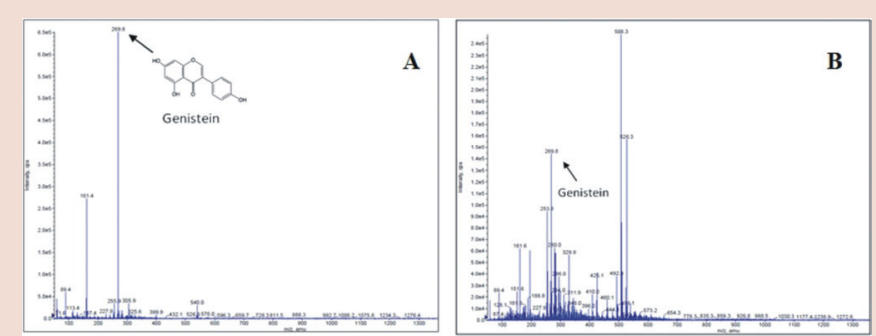

Figure 2: Full scan Q1 MS mass spectrum of A) standard genistein and B) ethanolic extract of $F$. vestita tubers

\section{Safety evaluation}

The data of the acute oral toxicity studies on medicinal plants is necessary in order to increase the confidence in its safety to human, particularly for use in the development of pharmaceuticals. ${ }^{30}$ Oral administration of the ethanolic extract of $F$. vestita tubers at a dose of $2000 \mathrm{mg} / \mathrm{kg}$ body weight did not show any toxic effect or mortality. Also, no significant change in the body weight, food intake and water intake of the animals was observed compared to the animals of control group. Hence, the extract had a wide margin of safety for oral use in rats (Data not shown).

\section{Evaluation of estrogenic potential}

Cage side observations during the efficacy study were found to be normal with no sign of abdominal dullness, subcutaneous slug, opacity and discharge for eyes and breathing abnormality.

\section{Vaginal Cellular Differentiation}

The estrous cycle is characterized by cyclical changes in uterus, ovaries, vaginal mucosa as well as behavioral and hormonal changes. ${ }^{31}$ Vaginal cytology assay is particularly used to determine the estrogenic activity of the synthetic estrogens and phytoestrogens ${ }^{21}$ as they induce the cornification of epithelial cells. After ovariectomy, all the rats had leukocytes population affirming complete removal of ovaries. ${ }^{32}$ Vaginal smears of OVX rats did not show any cornification proving the absence of endogenous estrogens. Vaginal cells showed maturation in response to Estradiol valerate in 5 days during the 15 day exposure period. Similar observations were reported by Cordial et al., 2006 using 17 $\beta$-Estradiol at a dose of $50 \mu \mathrm{g} / \mathrm{kg}$ bd. wt. ${ }^{2} \mathrm{FVH}$ induced significant cornification of cells when compared to OVX control on $9^{\text {th }}$ day whereas FVM and FVL induced cornification of epithelium cells after $10^{\text {th }}$ and $13^{\text {th }}$ day of the exposure period. There are many preclinical and clinical studies reported on the effects of phytoestrogens on vaginal cytology maturation. ${ }^{33-34}$ In our study, the cornification of vaginal smear in OVX rats treated with F. vestita tubers was found to be dose dependent which can be attributed to its estrogenic potential.

\section{Effect of ethanolic extract of $F$. vestita tubers on $17 \beta$-estradiol and Progesterone level}

Ovarian hormones, estrogen and progesterone govern the primary changes in the uterine tissue. ${ }^{8}$ All the animals after ovariectomy procedure showed significant decrease $(\mathrm{p}<0.001)$ in the $17 \beta$-estradiol and progesterone levels compared to the animals of normal control group before dosing indicating complete removal of ovaries. After treatment for 14 days, animals treated with estradiol valerate showed a significant increase $(\mathrm{p}<0.001)$ in the $17 \beta$-estradiol and progesterone levels compared to the animals of OVX control group. Similarly, animals treated with all the three doses of plant extract showed significant increase $(\mathrm{p}<$ 0.001 ) in $17 \beta$-estradiol and progesterone levels when compared with the OVX control. Amongst all the treatment doses, FVH showed maximum increase in the $17 \beta$-estradiol and progesterone levels indicating its dose dependent estrogenic potential (Table 1).

\section{Effect of ethanolic extract of $F$. vestita tubers on uterine weight}

Uteri undergo innumerable physiological and biochemical changes under the influence of ovarian hormones such as estrogen and progesterone. $^{8}$ Administration of estrogenic substances to ovariectomized rats often leads to proliferative changes in the uterine endometrium. ${ }^{35}$ Animals in OVX control showed significant decrease $(\mathrm{p}<0.001)$ in the uterine weight when compared with the normal control due to the loss of ovaries. Administration of estradiol valerate showed a significant $(\mathrm{p}<$ 0.001 ) increase in the uterine weight. Animals treated with FVL did not show significant increase in the uterine weight when compared with the OVX control. Animals treated with FVH and FVM showed significant increase $(\mathrm{p}<0.001)$ in the uterine weight when compared with OVX control (Table 2). Similar results have been reported earlier wherein plant extracts of estrogenic nature increased uterine weight in ovariectomized rat. ${ }^{36-37}$ Estrogenic potency and efficacy have traditionally been expressed in terms of uterotrophic effects in ovariectomized female rats. ${ }^{38}$ In this study, the increase in uterine wet weight was successive and gradual with the increase in dose of the extract of $F$. vestita.

\section{Effect of ethanolic extract of $F$. vestita tubers on uterine glycogen content}

The energy source for female reproductive system is glycogen and estrogens have been reported to increase the hexose transport into the rat uterus thereby increasing the synthesis of glycogen in the uterus. ${ }^{6,39}$ The decrease in levels of uterine glycogen in the OVX control may be due to the estrogen deficiency. Animals treated with the plant extract showed 
Table 1: Effect of $F$. vestita extract at three different doses and estradiol valarate on serum 17- $\beta$ estradiol and progesterone levels after ovariectomy at 0 day and $15^{\text {th }}$ day

\begin{tabular}{|c|c|c|c|c|}
\hline \multirow{2}{*}{$\begin{array}{c}\text { Treatment } \\
\text { groups }\end{array}$} & \multicolumn{2}{|c|}{$17-\beta$ estradiol ( $\mathrm{pg} / \mathrm{mL})$} & \multicolumn{2}{|c|}{ Progesterone (ng/mL) } \\
\hline & 0 day & $15^{\text {th }}$ day & 0 day & $15^{\text {th }}$ day \\
\hline NC & $26.68 \pm 0.19^{c}$ & $26.02 \pm 0.16^{c}$ & $7.04 \pm 0.05^{c}$ & $8.49 \pm 0.04^{c}$ \\
\hline OVX & $11.02 \pm 0.07^{* * *}$ & $11.52 \pm 0.14^{* * *}$ & $0.81 \pm 0.01^{* * *}$ & $0.95 \pm 0.01^{* * *}$ \\
\hline $\begin{array}{c}\mathrm{EV} \\
1 \mathrm{mg} / \mathrm{kg}\end{array}$ & $11.09 \pm 0.05^{* * *}$ & $22.83 \pm 0.10^{\mathrm{c} * *}$ & $0.79 \pm 0.01^{* * *}$ & $2.98 \pm 0.02^{c^{* * *}}$ \\
\hline $\begin{array}{c}\text { FVL } \\
100 \mathrm{mg} / \mathrm{kg}\end{array}$ & $10.89 \pm 0.04^{* * *}$ & $21.77 \pm 0.08^{c^{* * *}}$ & $1.17 \pm 0.01^{\mathrm{c}^{* * *}}$ & $1.25 \pm 0.01^{\mathrm{c}^{* * *}}$ \\
\hline $\begin{array}{c}\text { FVM } \\
250 \mathrm{mg} / \mathrm{kg}\end{array}$ & $11.04 \pm 0.04^{* * *}$ & $22.83 \pm 0.16^{\mathrm{c} * *}$ & $0.16 \pm 0.01^{\mathrm{c}^{* * *}}$ & $4.09 \pm 0.01^{\mathrm{c**x}}$ \\
\hline $\begin{array}{c}\text { FVH } \\
500 \mathrm{mg} / \mathrm{kg}\end{array}$ & $11.04 \pm 0.01^{* * *}$ & $25.15 \pm 0.26^{\mathrm{c}^{* *}}$ & $0.33 \pm 0.011^{\mathrm{c}^{* * *}}$ & $8.33 \pm 0.05^{c^{* *}}$ \\
\hline
\end{tabular}

Statistical significant compared with ovariectomized control a $\mathrm{p}<0.05,{ }^{\mathrm{b}} \mathrm{p}<0.01$, ${ }^{\mathrm{c}} \mathrm{p}<0.001$

Statistical significant compared with normal control ${ }^{*} \mathrm{p}<0.05$, ${ }^{* *} \mathrm{p}<0.01$, ${ }^{* * *} \mathrm{p}<0.001$

All values expressed as Mean \pm SEM; $\mathrm{n}=6$. SEM: Standard Error of Mean; NC: Normal Control (Sham-operated) rats; OVX: Ovariectomized rats; EV: OVX rats treated with Estradiol valerate; FVL, FVM and FVH are OVX rats treated with low dose, medium dose and high dose of ethanolic extract of $F$. vestita tubers respectively.

dose-dependent increase in the uterine glycogen content (Table 2). Significant increase in uterine glycogen content was observed in the animals treated with FVH ( $\mathrm{p}<0.001)$ when compared to the OVX control and the result was equivalent to the animals treated with estradiol valerate $(\mathrm{p}<0.001)$.

\section{Effect of ethanolic extract of $F$. vestita tubers on uterine G6PDH and $L D H$ levels}

G6PDH is the first enzyme in the pentose phosphate pathway which provides pentose phosphates and reducing equivalents in the form of NADPH. Estrogen is known to have a direct influence on glycogen synthesis and is a potent stimulator of G6PDH and LDH activities in the uterus of OVX rats. ${ }^{40}$ The OVX control showed significant decrease ( $\mathrm{p}<$ 0.001 ) in the G6PDH and LDH levels as compared to the normal control. Significant increase $(\mathrm{p}<0.001)$ in the levels of G6PDH and LDH (except G6PDH level in low dose; $p<0.05$ ) were observed in the animals treated with all the three doses of plant extract and estradiol valerate when compared with the OVX control (Table 2).

\section{Effect of ethanolic extract of F. vestita tubers on Cholesterol, HDL and Triglycerides}

Estrogen has been reported as a beneficial factor in preventing cardiovascular diseases like atherosclerosis by keeping plasma cholesterol levels low in premenopausal women. Postmenopausal women lose this protection because of dramatic decrease in estrogen levels as a result of natural atrophy of the ovaries..$^{41-42}$

Significant increase $(\mathrm{p}<0.001)$ in the cholesterol, HDL and triglycerides levels in OVX control were observed when compared to normal control group. Animals treated with the estradiol valerate showed significant decrease $(\mathrm{p}<0.001)$ in the levels of these markers as compared to OVX control. Significant reduction in the levels of cholesterol $(\mathrm{p}<0.01)$, HDL $(\mathrm{p}<0.001)$ and triglycerides $(\mathrm{p}<0.001)$ were observed in the rats treated with FVH as compared to the OVX control group (Table 2).

\section{Histopathological evaluation}

The uterine histology of the sham-operated rats showed single layered columnar epithelial cells (LE), numerous and irregular endometrial glands (EG). The compact arrangement of the myometrium (M) and perimetrium $(\mathrm{P})$ layer were also observed. The uterine section of OVX control rats revealed changes characterized by atrophy of the uterus and more intracellular spaces. There was noteworthy decrease in the number of endometrial glands (EG) with disappearance of lumen (LE) at some places, disorganization of epithelial cell lining and poor vascularity.

This condition was recovered by FVL which showed histological changes like hydrometra, epithelial proliferation and endometrial glandular hyperplasia. Animals treated with estradiol valerate showed intact luminal epithelium with low columnar cells and regular distribution of mitotic

Table 2: Effect of $F$. vestita extract at three different doses and estradiol valarate on uterine weight, glycogen content, G6PDH, LDH, cholesterol, HDL and triglycerides levels in ovariectomized rats

\begin{tabular}{|c|c|c|c|c|c|c|c|}
\hline $\begin{array}{l}\text { Treatment } \\
\text { groups }\end{array}$ & $\begin{array}{l}\text { Uterus weight } \\
\text { (mg/100g) }\end{array}$ & $\begin{array}{c}\text { Glycogen } \\
\text { content } \\
(\mathrm{mg} / \mathrm{g})\end{array}$ & $\begin{array}{l}\text { G6PDH } \\
\text { (Ug/Hb) }\end{array}$ & $\begin{array}{l}\text { LDH } \\
\text { (IU/L) }\end{array}$ & $\begin{array}{l}\text { Cholesterol } \\
\text { (mg/dL) }\end{array}$ & $\begin{array}{c}\text { HDL } \\
(\mathrm{mg} / \mathrm{dL})\end{array}$ & $\begin{array}{c}\text { Triglycerides } \\
\text { (mg/dL) }\end{array}$ \\
\hline \multirow{2}{*}{ NC } & 173.86 & 65.66 & 7.22 & 1123.64 & 52.23 & 41.34 & 46.92 \\
\hline & $\pm 0.42^{c}$ & $\pm 0.31^{\mathrm{c}}$ & $\pm 0.05^{c}$ & $\pm 0.44^{\mathrm{c}}$ & $\pm 0.34^{\mathrm{c}}$ & $\pm 0.33^{\mathrm{c}}$ & $\pm 0.27^{c}$ \\
\hline \multirow{2}{*}{ OVX } & 43.88 & 29.77 & 2.84 & 465.14 & 86.53 & 66.87 & 73.13 \\
\hline & $\pm 0.26^{* * *}$ & $\pm 0.19^{* * *}$ & $\pm 0.02^{* * *}$ & $\pm 0.46^{* * *}$ & $\pm 0.66^{* * *}$ & $\pm 0.48^{* * *}$ & $\pm 0.45^{* * *}$ \\
\hline EV & 117.41 & 44.89 & 4.88 & 765.02 & 56.84 & 44.57 & 58.59 \\
\hline $1 \mathrm{mg} / \mathrm{kg}$ & $\pm 0.80^{c^{* * *}}$ & $\pm 0.25^{\mathrm{c} * *}$ & $\pm 0.03^{c^{* * *}}$ & $\pm 0.76^{\mathrm{c}^{* * *}}$ & $\pm 0.38^{c^{* * *}}$ & $\pm 0.33^{c^{* * *}}$ & $\pm 0.43^{\mathrm{c}^{* * *}}$ \\
\hline FVL & 44.14 & 30.81 & 2.97 & 497.36 & 84.28 & 65.56 & 71.66 \\
\hline $100 \mathrm{mg} / \mathrm{kg}$ & $\pm 0.23^{* * *}$ & $\pm 0.22^{2^{* * *}}$ & $\pm 0.02^{\mathrm{a}^{* * *}}$ & $\pm 0.82^{\mathrm{c}^{* * *}}$ & $\pm 0.31^{\mathrm{b}^{* * *}}$ & $\pm 0.26^{* * *}$ & $\pm 0.21^{\mathrm{a} * * \star}$ \\
\hline FVM & 68.40 & 31.04 & 3.52 & 1003.39 & 84.19 & 65.18 & 54.46 \\
\hline $250 \mathrm{mg} / \mathrm{kg}$ & $\pm 0.40^{c^{* * x}}$ & $\pm 0.24^{\mathrm{b}^{* * *}}$ & $\pm 0.02^{c^{* * *}}$ & $\pm 0.71^{\mathrm{c}^{\star * \star}}$ & $\pm 0.19^{c^{* * *}}$ & $\pm 0.34^{\mathrm{b}^{* * *}}$ & $\pm 0.36^{\mathrm{c}^{* *}}$ \\
\hline FVH & 98.07 & 41.32 & 4.55 & 832.10 & 84.56 & 60.09 & 50.36 \\
\hline $500 \mathrm{mg} / \mathrm{kg}$ & $\pm 0.58^{\mathrm{c}^{* * *}}$ & $\pm 0.29^{c^{* * *}}$ & $\pm 0.03^{\mathrm{c}^{* * *}}$ & $\pm 0.76^{\mathrm{c} * *}$ & $\pm 0.22^{\mathrm{b}^{* * *}}$ & $\pm 0.36^{\mathrm{c}^{* * *}}$ & $\pm 0.31^{\mathrm{c}^{* * *}}$ \\
\hline
\end{tabular}

Statistical significant compared with ovariectomized control ${ }^{\mathrm{a}} \mathrm{p}<0.05,{ }^{\mathrm{b}} \mathrm{p}<0.01,{ }^{\mathrm{c}} \mathrm{p}<0.001$

Statistical significant compared with normal control ${ }^{*} \mathrm{p}<0.05,{ }^{* *} \mathrm{p}<0.01,{ }^{* * *} \mathrm{p}<0.001$

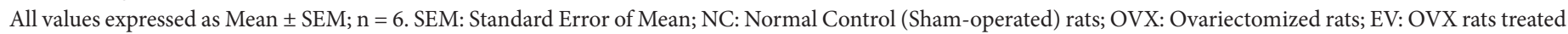

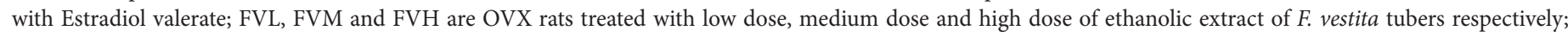
G6PDH: Glucose-6-phosphate dehydrogenase; LDH: Lactate dehydrogenase; HDL: High-density lipoprotein. 


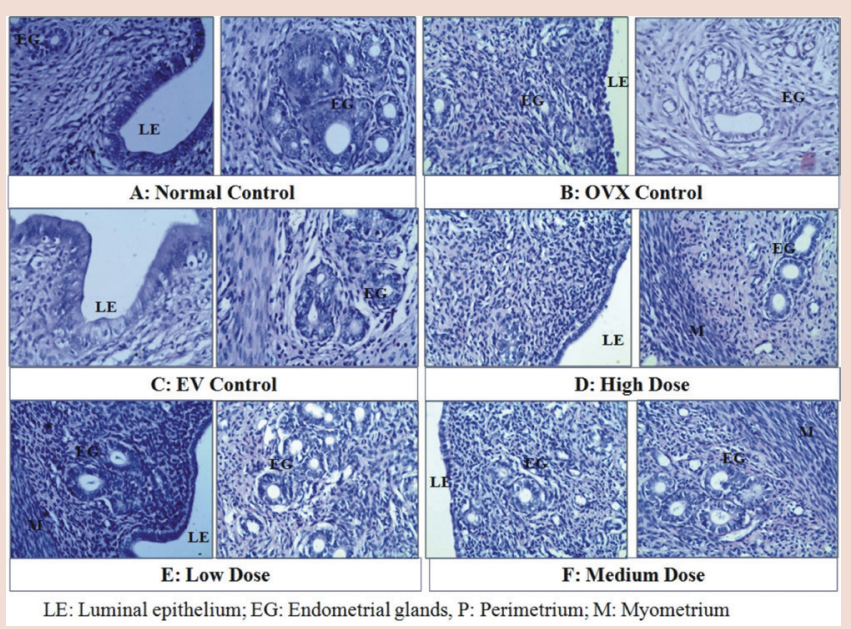

Figure 3: Photomicrograph of Hematoxylin and eosin stained tissue crosssections of endometrium layer of the uterus under $400 \mathrm{X}$ magnification (A) Vehicle treated normal control rats; (B) Ovariectomised control rats; (C) Ovariectomised rats treated with estradiol valerate (1 mg/kg); (D) Ovariectomised rats treated with FVL (100 mg/kg);

(E) Ovariectomised rats treated with FVM $(250 \mathrm{mg} / \mathrm{kg})$; (F) Ovariectomised rats treated with $\mathrm{FVH}(500 \mathrm{mg} / \mathrm{kg})$

$\mathrm{LE}=$ Luminal epithelium; $\mathrm{EG}=$ Endometrial glands; $\mathrm{P}=$ Perimetrium $M=$ Myometrium

figures. Endometrial layer showed increase in the number of endometrial glands as well as developed vascular layer and connective tissue.

However, FVH was effective than OVX control, FVL and FVM and caused changes in the uterus which exhibited hypertrophy of stromal and endometrial glandular cells, epithelial hyperplasia and increased vascularity. Endometrial layer was well developed with more number of endometrial glands lined with simple columnar epithelium. FVH was found to be more effective on proliferation of endometrial glands than on the luminal epithelium (Figure 3). An increased mitotic activity of uterine tissues was clearly evident in the animals treated with high dose of plant extract indicating its estrogenic nature. ${ }^{43}$

Estrogenic potential of the ethanolic extract of $F$. vestita tubers at three dose levels was evaluated in OVX female albino Wistar rat model in terms of biochemical markers such as estrogen, progesterone, $\mathrm{LDH}$, G6PDH, cholesterol, HDL, triglycerides, uterine weight and uterine glycogen content.

Marked recovery of these biochemical markers were observed in the animals treated with $F$. vestita tubers as compared to OVX control group indicating estrogenic potential of this plant and results were at par with the estradiol valerate treatment. The improved histoarchitecture of the uterus was observed in histopathological evaluation of animals treated with the ethanolic extract of $F$. vestita tubers as compared to the animals of OVX control group. This indicates the ability of plant to proliferate luminal epithelium and endometrial cells. Thus, the estrogenic activity shown by ethanolic extract of $F$. vestita tubers can be attributed to the presence of phytoestrogens like genistein.

From the above observations it can be concluded that the standardized ethanolic extract of $F$. vestita tubers at high dose level showed the promising effects on the physical, histological and biochemical parameters of the uterine tissue.

\section{CONCLUSION}

Findings of the current study, therefore suggest that the extract could form a basis for phytotherapeutic preparations which might help raise the market value of F. vestita tubers. Such plants can also be used as an alternative therapy for menopausal syndrome.

\section{ACKNOWLEDGEMENT}

We acknowledge the financial assistance from the Department of Biotechnology, Government of India under Twinning Program with North East Hill University (Sanction No. BT/250/NE/TBP/2011).

\section{ABBREVIATION USED}

CMC: Carboxy Methyl Cellulose, CPCSEA: Committee for the Purpose of Control and Supervision of Experiments on Animals, G6PDH: Glucose 6 phosphate dehydrogenase, HDL: High density lipoprotein; HPLC: High Performance Layer Chromtography, LC-MS: Liquid Chromatography-Mass Spectrometry, LDH: Lactate dehydrogense, OECD: Organization for Economic Cooperation and Development.

\section{REFERENCES}

1. El-Halawany AM, Chung MH, Nakamura N, Ma C, Nishihara T, Hattori M. Estrogenic and Anti-estrogenic activities of Cassia tora Phenolic Constituents. Chem Pharm Bull. 2007; 55(10): 1476-82.

2. Cordial RR, Baxa-Daguplo BM, Fermanes PMS, Garcia AS, Clavel RMM, Herradura Mo, et al. Estrogenic Activity of Pueraria phaseoloides Roxb. Benth Evaluated in Ovariectomized Rats. Philipp J Sci. 2006; 135(1): 39-48.

3. Yadav R, Jain GC. Influence of Cassia fistula seeds extract on uterine histoarchitecture and biochemical constituents of ovariectomized female rats. Cibtech Journal of Zoology 2012; 1(2): 57-66

4. Hong MA, Chung MH, Nishihara YT, Hattori M. Estrogenic effects of the herbal formula, Menprogen in ovariectomized rats. Biol Pharm Bull. 2010; 33(3): 455-60.

5. Circosta C, Pasquale RD, Palumbo DR, Samperi S, Occhiuto F. Estrogenic Activity of Standardized Extract of Angelica sinensis. Phytother Res. 2006; 20(8): 665-9.

6. Mitra SK, Madhumathi BG, Gopumadhavan S, Venkataranganna MV, Mohamed $R$. Evaluation of the estrogenic effect of Menosan using the rat models of uterotrophic assay. Medicine Update 2005; 13(1): 37-41.

7. Gopumadhavan S, Venkataranganna MV, Mohamed Rafiq SJ, Seshadri Mitra SK. Uterotrophic Effect of Menotab (M-3119): A Preclinical Study. Indian J Pharmacol. 2002; 34(4): 237-43.

8. Mitra SK, Gopumadhavan S, Venkataranganna MV, Sharma DNK, Anturlikar SD. Uterine tonic activity of U-3107, a herbal preparation in rats. Indian J Pharmacol. 1999; 31 (Issue Missing?): 200-3.

9. Songachan LS, Kayang H. Diversity and species composition of arbuscular mycorrhizal fungi in Flemingia vestita under shifting and continuous cropping system. NeBIO. 2011; 2(4): 1-8.

10. Kar PK, Tandon V, Saha N. Anthelmintic efficacy of Flemingia vestita: genistein induced effect on the activity of nitric oxide synthase and nitric oxide in the trematode parasite, Fasciolopsis buski. Parasitol Int. 2002; 51(3): 249-57.

11. Roy B, Tandon V. Effect of root tuber extract of Flemingia vestita, a leguminous plant, on Artyfechinostomum sufrartyfex and Fasciolopsis buski: a scanning electron microscopy study. Parasitol Res. 1996; 82(3): 248-52.

12. Tandon $\mathrm{V}$, Pal $\mathrm{P}$, Roy $\mathrm{B}$, Rao HSP, Reddy KS. In vitro anthelmintic activity of root tuber extract of Flemingia vestita, an indigenous plant in Shillong, India. Parasitol Res. 1997; 83(5): 492-8.

13. Rao HSP, Reddy KS. Isoflavones from Flemingia vestita. Fitoterapia 1991; 62(5): 458.

14. Tandon $\mathrm{P}$, Kumaria $\mathrm{S}$, Kayang $\mathrm{H}$. Conservation of medicinal and aromatic plants of Northeast India. In: Ahmad A, Siddiqi TO, Iqbal M, editors. Medicinal Plants in Changing Environment, New Delhi: Capital Publishing Company; 2010. p. 202-12.

15. Ghalot K, Lal VK, Jha S. Phytochemical and Pharmacological potential of Flemingia Roxb. ex W. T. Aiton (Fabaceae). International Journal of Phytomed. 2011; 3(3): 294-307.

16. Lee GK, Choi KC, Kim HJ, Jeung EB. Effect of Genistein as a Selective Estrogen Receptor Beta Agonist on the Expression of Calbindin - $D_{9 k}$ in the Uterus of Immature Rats. Toxicological Sciences 2004; 82(2): 451-7.

17. Santell RC, Kieu N, Helferich WG. Genistein Inhibits Growth of Estrogen-Independent Human Breast Cancer Cells in Culture but Not in Athymic Mice. J. Nutr. 2000; 130(7): 1665-9.

18. Picherit C, Coxam V, Bennetau-Pelissero C, Kati-Coulibaly S, Davicco MJ, Lebecque $\mathrm{P}$, et al. Daidzein is more efficient than genistein in preventing ovariectomy-induced bone loss in rats. J Nutr. 2000; 130(7): 1675-81.

19. Shailajan S, Kumaria S, Pednekar S, Menon S, Joshi H, Matani A. Chromatographic evaluation of a phytoestrogen Genistein from Flemingia vestita Benth: An endemic plant of Northeast India. Phcog Commn. 2014; 4(4): 2-8. 
20. OECD guidelines for the testing of chemicals 2011. [home page of OECD iLibrary]. [online]. Available: http://apps.who.int/medicinedocs/en/d/Jh2946e/ 4.6.html. 2012, July 14.

21. Malaivijitnond S, Chansri K, Kijkuokul P, Urasopon N, Cherdshewasart W. Using vaginal cytology to assess the estrogenic activity of phytoestrogen-rich herb. $J$ Ethnopharmacol. 2006; 107(3): 354-60

22. Sahar MMO, Abeer A. Modified vaginal smear cytology for the determination of the rat estrous phases, versus ordinary papanicolaou technique, verified by light and scanning electron microscopic examination of the endometrium. The Egyptian Journal of histology 2007; 30(2): 397-408.

23. Lasota A, Danowska-Klonowska D. Experimental osteoporosis- different methods of ovariectomy in female white rats. Annales Academiae Medicae Bialostocensis 2004; 49(Suppl): 129-31.

24. Parhizkar S, Rashid I, Latiffah AL. Incision Choice in Laparatomy: a Comparison of Two Incision Techniques in Ovariectomy of Rats. World Appl Sci J. 2008; 4(4): 537-40.

25. Stomati M, Bernardi F, Luisi S, Puccetti S, Casarosa E, Liut M, et al. Conjugated equine estrogens, estrone, sulphate and estradiol valerate oral administration in ovariectomized rats: effects on central and peripheral allopregnanone and beta endorphin. Maturitas 2002; 43(3): 195-206.

26. Dayton SS, Novice SB, Muntwryler E. The Estimation of Glycogen with Anthrone Reagent. Arch. Biochem. Biophy. 1980; 25(2775): 191-5.

27. Mercer EH, Birbeck MSC. Electron Microscopy: A Handbook for Biologists. $2^{\text {nd }}$ ed. Blackwell Scient. Publ; 1966.

28. Adlercreutz H. Phytoestrogens and breast cancer. J Steroid Biochem Mol Biol. 2002; 83(1): 113-8.

29. Dixon RA, Ferreira D. Molecules of Interest Genistein. Phytochem. 2002; 60(3): 205-11.

30. Rajalakshmi A, Jayachitra A, Gopal P, Krithiga N. Toxicity Analysis of different medicinal plant extracts in Swiss Albino Mice. Pharmacology and Toxicology Research 2014; 1(2): 1-6.

31. Mary KF, Eswaramohan T, Surendran SN, Murugananthan A, Romakeswaran P. Mukkuddu Maathrai (Triple Tablet), An Indigenous Medicine Elevates Serum Prolactin Level of Female Rats (Rattus norvegicus). IOSR Journal of Pharmacy 2013; 3( ): 38-42.

32. Jawaid T, Awasthi A, Kamal M. Estrogenic activity of a hydro-alcoholic extract of Bambusa arundinaceae leaves on female wistar rats. J Adv Pharm Technol Res. 2015; 6(1): 19-24.

33. Wilcox G, Wahlqvist ML, Burger HG, Medley G. Oestrogenic effects of plant foods in postmenopausal women. British Medical Journal 1990; 301(6757): 905-6.

34. Alam Q, Vijayanarayana K, Satyanarayana D. Evaluation of estrogenic activity of alcoholic extract of fruits of Solanum xanthocarpum using uterine wet weight, uterine glycogen content and uterine histology as parameter of assessment. Int. J. Pharm. and Bio. Sci. 2012; 1(2): 99-108.

35. Williamson EM, Okpako DT, Evans FJ. Endocrine Activity: Antifertility and Sex Hormornes. In: Pharmacological Methods in Phytotherapy Research- Selection, Preparation and Pharmacological Evaluation of Plant Material. Vol. 1. Chapter.11. New York: John Wiley and Sons; 1996. p. 191-6.

36. Sookvanichsilp N, Soonthornchareonnon N, Boonleang C. Estrogenic activity of the dichloromethane extract from Pueraria mirifica. Fitoterapia 2008; 79(7-8) 509-14.

37. Pathak S, Prakash AO. Effect of hexane extract of Ferula jaeschkeana on the uterus of adult ovariectomized rats. Anc. Sci. Life 1992; 12(1-2): 231-41.

38. Ruentiz PC. Female Sex Hormones, Contraceptives, and Fertility Drugs. In: Abraham DJ, editor. Burger's Medicinal Chemistry and Drug Discovery. Vol 3. Chapter.13. USA: John Wiley and Sons Inc; 2003. p. 629 - 60.

39. Vijayanarayana K, Rodrigues RS, Chandrashekhar KS, Subrahmanyam EV. Evaluation of estrogenic activity of alcoholic extract of rhizomes of Curculigo orchioides. J Ethnopharmacol. 2007; 114(2): 241-5.

40. Mckerns KW. Gonadotropin regulation of the activities of dehydrogenase enzymes of the ovary. Biochimica et Biophysica Acta. 1965; 97(3): 542-50.

41. Kim-Schulze S, McGowan KA, Hubchak SC, Cid MC, Martin MB, Kleinman HK et al. Expression of an estrogen receptor by human coronary artery and umbilical vein endothelial cells. Circulation 1996; 94(6): 1402-7.

42. Zaid SS, Sulaiman SA, Sirajudeen KNM, Othman NH. The effect of tualang honey on female reproductive organs, tibia bone and hormonal profile in ovariectomized rats - animal model for menopause. 2010, BMC Complement. Altern. Med. 2010; 10: 82

43. Malini T, Vanithakumari G. Comparative progesterone study of the effects of $\beta$-sitosterol, estradiol and on selected biochemical parameters of the uterus of ovariectomised rats. J Ethnopharmacol. 1992; 36(1): 51-5.

\section{PICTORIAL ABSTRACT}

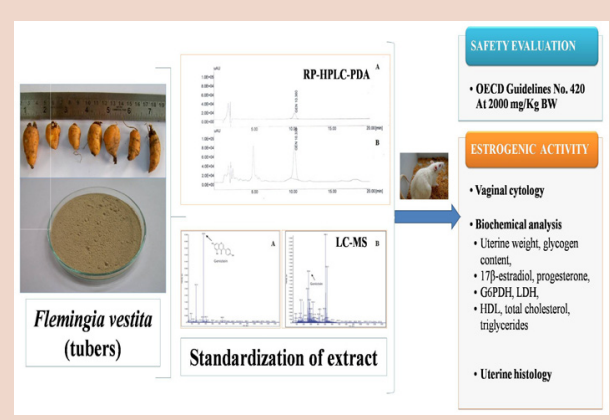

\section{SUMMARY}

- The ethanolic extract of $F$. vestita tubers was standardized in terms of genistein content $(8.43 \pm 0.05 \mathrm{mg} / \mathrm{g}$ of extract) using validated HPLC method.

- Presence of genistein in the ethanolic extract of $F$. vestita tubers was confirmed using LC/MS technique ( $\mathrm{m} / \mathrm{z}$ ratio: 269.8).

- The standardized extract of $F$. vestita tubers was found to be safe in albino Wistar rats at a dose of $2000 \mathrm{mg} / \mathrm{kg}$ body weight using OECD Guideline no. 420.

- Estrogenic potential of $F$. vestita tubers extract at three dose levels was evaluated in ovariectomized rat model.

\section{ABOUT AUTHOR}

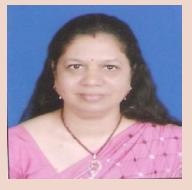

Dr. Sunita Shailajan: Is an Associate Professor in Botany, Incharge of Herbal Ressearch Lab and Scientist Incharge of Animal Testing Centre at Ramnarain Ruia College, University of Mumbai, India. She is recognized research guide in the subject of Botany, Bioanalytical Sciences, Biotechnology and Applied Biology. Her specialization is in the area of standardization of herbal raw materials and ASU formulations, instrumentation (HPTLC and HPLC), bioanalytical method validation, pharmacokinetic studies. She has more than 90 scientific publications and made presentations in various National and International conferences in India and overseas. She has been working as Principal Investigator for Government funded projects. 